pneumonia, organism unspecified or Pneumocystis carinii pneumonia; most of the remainder were conditions known to be associated with but not specific to AIDS.

As the excess deaths were calculated only from the beginning of 1985, although some deaths due to AIDS are known to have occurred before then, the number underestimates the total deaths due to AIDS since the syndrome was first recognised in the United Kingdom. The 1984 baseline was adjusted to take account of the small increase in the population estimates of men in each succeeding year.

Some of the excess deaths may not have been associated with HIV infection. If this were so the increase in deaths is difficult to explain, particularly as about $90 \%$ of them occurred in men who had never been married, and these men represent only $40 \%$ of men aged $15-54$. The deficit of deaths due to causes other than those possibly related to HIV infection suggests that the selection was generally appropriate. The deficit of deaths among women aged 15-54 emphasises the difference in the change in mortality between the sexes.

Infection with HIV may predispose to the development of clinical conditions that are not currently recognised as being associated with the virus. As the number of deaths after HIV infection increases analysis of other conditions mentioned on death certificates stating AIDS or HIV infection as the underlying cause of death and of trends in deaths attributed to other causes may help to identify a wider range of clinical manifestations.

Of the total 495 estimated excess deaths in men, in only 198 was the cause of death coded as AIDS by this office, leaving an estimated 297 coded as other causes. AIDS or HIV infection is therefore considerably understated as the cause of death. This is confirmed by the number of cases of AIDS reported to the Communicable Disease Surveillance Centre in which AIDS was not recorded on the death certificate. In some cases the correct diagnosis may not have been made at the time of death or the doctor may not have wished to mention AIDS on the certificate and did not subsequently send this information to this office. The increase in mortality rate in men who had never been married may be due to some manifestation of HIV infection other than the syndrome recognised as AIDS. Accurate reporting of the underlying cause and other conditions present at the time of death is necessary if illness not currently known to be associated with HIV infection is to be identified.

I am indebted to my statistician colleagues at this office, Michael Day and Tim Devis, for their invaluable help in preparing this paper.

\section{References}

Births and Deaths Registration Act 1953. London: HMSO, 1953:S22.

Coroners (Amendment) Act 1926. London: HMSO, 1926:S20.

3 Births and Deaths Registration Act 1953. London: HMSO, 1953:S23.

4 Alderson MR, Bayliss RIS, Clarke CA, Whitfield AGW. Death certification. Br Med $\mathcal{f}$ 1983;287:444-5.

5 Medical Services Study Group of the Royal College of Physicians of London. Death certification and epidemiological research. Br Med $\mathcal{F}$ 1978;ii: 1063-5.

6 Kristal AR. The impact of the acquired immunodeficiency syndrome on patterns of premature death in New York City. FAMA 1986;255:2306-10.

7 Centers for Disease Control. Revision of the CDC case definition for acquired immunodeficiency syndrome. $M M W R$ 1987;36(suppl):IS.

8 Office of Population Censuses and Surveys. 1984 Mortality Statistics. Series DH2. No 11. London: HMSO, 1985:v-vii.

(Accepted 17 March 1988)

\title{
Graves' disease: immunological and immunogenetic indicators of relapse
}

\author{
T W A DE BRUIN, J H BOLK, J K BUSSEMAKER, T STIJNEN, G M T SCHREUDER, \\ R R P DE VRIES, D VAN DER HEIDE
}

\begin{abstract}
The use of measurements of antibody to the thyroid stimulating hormone receptor and HLA-DR3 phenotype for predicting relapse of hyperthyroidism in patients with Graves' disease receiving medical treatment is controversial. Fifty eight new patients with Graves' disease were followed up prospectively for up to 96 months after treatment with antithyroid drugs for 12 months. The presence of antibody to the thyroid stimulating hormone receptor before the start of treatment, measured as immunoglobulins inhibiting binding of thyroid stimulating
\end{abstract}

\footnotetext{
Departments of Endocrinology, Internal Medicine, Medical Statistics, and Immunohaematology, University Hospital, 2333 AA Leiden, The Netherlands

T W A DE BRUIN, MD

J H BOLK, MD

J K BUSSEMAKER

T STIJNEN, PHD

G M T SCHREUDER, PHD

R R P DE VRIES, $M$ D

D VAN DER HEIDE, PHD

Correspondence to: Dr T W A de Bruin, Department of Endocrinology, University Hospital, 3511 GV Utrecht, The Netherlands.
}

hormone, was not associated with relapse. Patients who remained positive for antibodies after treatment tended to relapse within six months, but no relation with long term relapse was found. HLA-Cw7 but not HLA-DR3 was significantly associated with relapse. The presence of HLA-DR4 was significantly associated with remission and with absence of antibodies to thyroid stimulating hormone receptor. HLA-DR4 may therefore protect against relapse of thyrotoxicosis by immunomodulation triggered by antithyroid drugs, which results in the synthesis of antibodies to the thyroid stimulating hormone receptor being inhibited.

\section{Introduction}

Graves' disease is characterised by hyperfunctioning of the thyroid, which is caused by antibodies to the thyroid stimulating hormone receptor. ${ }^{2}$ The natural course of the disease includes periods of spontaneous remission and recurrence. ${ }^{3}$ After treatment with thionamide drugs about $40-60 \%$ of patients relapse..$^{3-5}$ The ability to predict recurrence is important as treatment by operation or with iodine-131 may be better for such patients. As relapse of hyperthyroidism is probably mediated immunologically ${ }^{12}$ there may be immunological factors that are of prognostic value. Graves' disease is associated with the histocompatibility antigen HLA-DR3. ${ }^{26}$ Initially, the presence of HLA-DR3 and of antibody to the thyroid 
stimulating hormone receptor antibody at the end of treatment, alone and in combination, were reported to be predictors of short term relapse ${ }^{26.8}$; most workers, however, have been unable to relate long term outcome to the presence of HLA-DR3. ${ }^{269-11}$

We followed up 58 new patients with Graves' disease prospectively. The long term outcome after a 12 month course of antithyroid drugs was evaluated for a possible association with antibody to the thyroid stimulating hormone receptor and the full array of HLA-A, B, C, DR, and DQ antigens.

\section{Patients and methods}

From January 1978 to December 1979 we treated 58 new patients (44 women and 14 men, aged 15-76) with Graves' disease. The diagnosis was based on the history, results of physical examination, and laboratory determinations of thyroid state including serum thyroxine and triiodo- occurring within 48 months. Each patient was followed up for at least 48 months.

Autoimmune markers-Serum samples were taken before treatment and at regular intervals thereafter; in each sample the presence of antibodies to the thyroid stimulating hormone receptor, microsomal antibodies, and circulating immune complexes and thyroid function were determined. Antibodies to the thyroid stimulating hormone receptor were detected by assay of the ability of gammaglobulin fractions of the serum to inhibit binding of radioiodinated thyroid stimulating hormone to human thyroid plasma membranes. ${ }^{13}$ Results were expressed as an index of inhibition of thyroid stimulating hormone binding, and serum samples were considered to be positive when the index was below 68 (mean index for 96 normal subjects minus $2 \mathrm{SD}){ }^{13}$ Microsomal antibody was measured by a standard haemagglutination assay (Fujirebio, Japan) and circulating immune complexes by an assay of binding of $\mathrm{Clq} .{ }^{13}$

HLA typing-The major histocompatibility antigens at the HLA-A $(\mathrm{n}=21$ with splits), B ( $n=46$ with splits), C ( $n=7), D R(n=10)$, and DQ ( $n=3)$ loci were typed by the department of immunohaematology. The HLA-A, B, and $C$ loci were typed according to the National Institutes of Health

TABLE I-Relation between variables studied and outcome. Values are numbers (percentages) of patients

\begin{tabular}{|c|c|c|c|c|c|}
\hline & $\begin{array}{l}\text { All patients } \\
(\mathrm{n}=58)\end{array}$ & $\begin{array}{l}\text { Patients who relapsed } \\
\qquad(\mathrm{n}=32)\end{array}$ & $\begin{array}{l}\text { Patients in remission } \\
\qquad(\mathrm{n}=26)\end{array}$ & Relative risk & $\mathrm{p}$ Value \\
\hline \multicolumn{6}{|c|}{ Antibody to thyroid stimulating hormone receptor present: } \\
\hline Before treatment & 33 & $21(64)$ & $12(36)$ & 1.45 & 0.22 \\
\hline After treatment & 5 & $4(80)$ & $1(20)$ & 1.51 & $0 \cdot 26$ \\
\hline HLA-DR4 present & 11 & $2(18)$ & $9(82)$ & 0.29 & 0.016 \\
\hline HLA-Cw7 present & 30 & $22(73)$ & $8(27)$ & 2.05 & 0.009 \\
\hline Goitre (enlarged threefold or more) & 11 & $8(73)$ & $3(27)$ & $1 \cdot 42$ & $0 \cdot 24$ \\
\hline Eye signs (class 2 or worse) & 28 & $14(50)$ & $14(50)$ & 0.83 & 0.54 \\
\hline
\end{tabular}

${ }^{\star} \chi^{2}$ Analysis $(2 \times 2$ tables $)$.

thyronine concentrations, triiodothyronine resin uptake, and microsomal antibody titre. The size of the goitre was estimated by palpation. Thirty two patients, including four with asymmetric goitres, underwent thyroid scintiscanning to confirm diffuse uptake of radioactivity. Eye signs were scored according to the classification of the American Thyroid Association ${ }^{12}$; those in class 2 or worse were considered to be specific for Graves' disease and were found in 28 patients.

Antithyroid treatment (propylthiouracil $300 \mathrm{mg} /$ day (38 patients), methimazole $30 \mathrm{mg} /$ day (eight), or carbimazole $30 \mathrm{mg} /$ day (12)) was given for a mean of $12 \cdot 2$ (SD 0.7$)$ months as described before. ${ }^{13}$ When the patients became euthyroid, usually after two to six weeks, thyroxine (up to $150 \mu \mathrm{g} /$ day) or thyroid $(50-75 \mathrm{mg} /$ day) was given in addition. Relapse was defined as the recurrence of symptoms and signs and biochemical evidence of hyperthyroidism; short term relapse was arbitrarily defined as that occurring within six months after the end of treatment and long term relapse as that

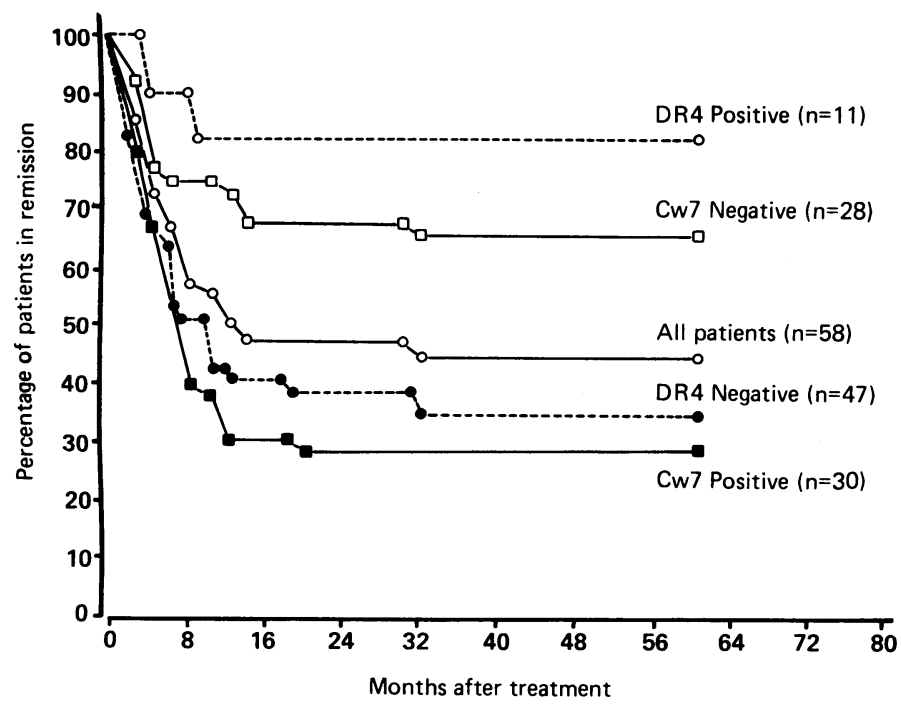

Relapse of Graves' disease after treatment in 58 patients and its relation to presence or absence of HLA-DR4 and Cw7. technique, ${ }^{14}$ and the HLA-DR and DQ loci by a two colour fluorescence lymphocytotoxicity assay, ${ }^{15}$ using a set of 200 highly selected serum samples. Five hundred and five healthy Dutch white subjects were randomly selected to serve as controls.

Statistical analysis-The relation between relapse and the index of inhibition of thyroid stimulating hormone binding, HLA specificity, size of goitre, and eye signs was evaluated by $\chi^{2}$ analysis $(2 \times 2 \text { tables })^{16}{ }^{17} ; \mathrm{p}$ values were not corrected for the number of antigens tested except where specified. ${ }^{18}$

\section{Results}

Thirty four patients relapsed from two weeks to 96 months (median four months) after treatment, 32 within 60 months (figure). Two patients relapsed 64 and 96 months after treatment, respectively; they were regarded as being in remission for the analysis of long term relapse. Short term relapse occurred in 23 patients. None of the patients became hypothyroid after treatment.

Table I summarises the relation of certain clinical and immunogenetic variables with long term relapse. Before treatment 33 patients had antibodies to thyroid stimulating hormone receptor; the index of inhibition of thyroid stimulating hormone binding was significantly lower in these patients than in the 25 who did not have such antibodies $(53 \cdot 1$ (SD) 11.7) $v(83 \cdot 2(9 \cdot 9)$, $\mathrm{p}<0.001$, Student's $t$ test). After treatment 53 patients did not have antibodies to the thyroid stimulating hormone receptor; five remained positive for these antibodies, and four of them relapsed within three months after treatment (odds ratio 3.57). The mean index of inhibition of binding of thyroid stimulating hormone initially was significantly lower in these five patients than in the 28 other patients who were antibody positive $(44 \cdot 6(9 \cdot 0)$ $v(54.6(11.6), \mathrm{p}<0.001$, Student's $t$ test). The presence of antibodies to thyroid stimulating hormone receptor initially did not predict the occurrence of short term $(p=0.44)$ or long term $(p=0 \cdot 22)$ relapse, whereas the presence of antibodies at the end of treatment was almost significantly associated with short term $(p=0.056)$ but not long term relapse (table I). The prevalence of the HLA-B8 (36\%) and HLA-DR3 (45\%) phenotypes was appreciably increased in the patients compared with the normal population ( $23 \%$ and $25 \%$, respectively). Short term relapse occurred in 23 patients and was associated with the absence of HLA-DR4 (22 patients, $p=0.05)$ and, marginally, the presence of HLA-Cw7 (16 patients, $p=0.053$ ). Long term relapse was also significantly associated with the absence of HLA-DR4 ( $p=$ $0.016)$ and the presence of HLA-Cw7 $(p=0.009)$ (table I). It was striking 
that the two patients positive for HLA-DR4 who relapsed were also positive for HLA-Cw7 whereas the nine others positive for HLA-DR4, who did not relapse, were negative for HLA-Cw7. No significant relation was found between relapse or remission and HLA-DR3 $(p=0.25)$ or HLA-DR2 $(p=$ $0 \cdot 17$ ), which is in linkage disequilibrium with HLA-Cw7, or any of the HLA-A, B, C, DR, and DQ phenotypes. Four of the five patients who remained positive for antibody to thyroid stimulating hormone receptor during treatment relapsed within three months after treatment; all four were negative for HLA-DR4, as might have been expected, and also, unexpectedly, for HLA-Cw7.

The absence of antibody to thyroid stimulating hormone receptors before the start of treatment was associated with the presence of HLA-DR4 $(p=$ $0.028)$ but not $\mathrm{Cw} 7(\mathrm{p}=0.81)$ (table II). No relation was observed between microsomal antibodies or circulating immune complexes and any HLA phenotype.

TABLE II-Relation of HLA-DR4 and Cw7 with antibody to thyroid stimulating hormone receptor, microsomal antibody, and circulating immune complexes during treatment with antithyroid drugs

\begin{tabular}{|c|c|c|c|c|}
\hline & \multicolumn{2}{|c|}{ DR4 $(n=11)$} & \multicolumn{2}{|c|}{ Cw7 $(n=30)$} \\
\hline & $\begin{array}{c}\text { No of } \\
\text { patients }\end{array}$ & Significance $^{\star}$ & $\begin{array}{c}\text { No of } \\
\text { patients }\end{array}$ & Significance $^{\star}$ \\
\hline \multicolumn{5}{|c|}{$\begin{array}{l}\text { Antibody to thyroid stimulating } \\
\text { hormone receptor: }\end{array}$} \\
\hline $\begin{array}{l}\text { Present }(n=33) \\
\text { Absent }(n=25)\end{array}$ & $\begin{array}{l}2 \\
9\end{array}$ & $\mathrm{p}=0.028$ & $\begin{array}{l}18 \\
12\end{array}$ & $p=0.81$ \\
\hline \multicolumn{5}{|c|}{ Microsomal antibody: } \\
\hline $\begin{array}{l}\text { Present }(n=54) \\
\text { Absent }(n=4)\end{array}$ & $\begin{array}{r}10 \\
1\end{array}$ & $\mathrm{p}=0.37$ & $\begin{array}{r}26 \\
4\end{array}$ & $p=0.48$ \\
\hline \multicolumn{5}{|c|}{ Circulating immune complexes: } \\
\hline $\begin{array}{l}\text { Present }(n=42) \\
\text { Absent }(n=16)\end{array}$ & $\begin{array}{l}7 \\
4\end{array}$ & $p=0.97$ & $\begin{array}{r}23 \\
7\end{array}$ & $p=0 \cdot 10$ \\
\hline
\end{tabular}

$\chi^{2}$ Analysis ( $2 \times 2$ tables $)$.

The size of the goitre, which is an established risk factor for relapse, was found to be significantly greater in the patients who relapsed $(2.35(1.0)$ times normal size) than in those in remission $(1 \cdot 8(0 \cdot 6)$ times normal size $)$ $(p<0.01)$; eight of the 11 patients whose goitres were enlarged threefold relapsed within 48 months $(p=0 \cdot 24)$ (table I). The presence of eye signs could not be related to long term relapse $(p=0.54)$, and the antithyroid drugs prescribed were not associated with relapse (data not shown).

Logistic regression analysis of data on HLA-Cw7 and DR4 specificities, threefold enlargement of the goitre, and the presence of antibody to the thyroid stimulating hormone receptor at the end of treatment showed that only HLA-Cw7 (estimated odds ratio $2 \cdot 75, \mathrm{p}=0.003$ ) and HLA-DR4 (estimated odds ratio $0.36, p=0.03$ ) were significant and independent risk factors.

\section{Discussion}

Our 58 patients were representative of all patients with Graves' disease as the rate of recurrence of thyrotoxicosis within four years after treatment $(55 \%)$ and the prevalence of eye signs $(48 \%)$, HLA-B8 (36\%) and HLA-DR3 (45\%) antigens, autoimmune markers such as antibodies to the thyroid stimulating hormone receptor $(57 \%)$, microsomal antibody $(93 \%)$, and circulating immune complexes (72\%) compared favourably with those reported previously. ${ }^{24691319-22}$ The frequency of antibodies to the thyroid stimulating hormone receptor (57\%) was lower than in our previous report $(72 \%)$; we cannot explain this as the same assay was used in both studies.

Four of the five patients in our study who remained positive for antibody to thyroid stimulating hormone receptor during treatment relapsed. A similar association between antibodies during treatment and relapse has been reported in previous prospective studies. ${ }^{482021}$ As in other prospective studies, ${ }^{7-11}$ however, we found that the presence of antibodies before treatment did not predict relapse; this conflicts with claims based on retrospective studies. ${ }^{26}$ This difference in results may be due to an unwanted selection of patients but is not related to differences in duration of treatment or follow up. ${ }^{267}$ Enlargement of the goitre is a well known risk factor for relapse ${ }^{42}$ and often influences the management of patients with Graves' disease. ${ }^{22}$ The goitre was significantly larger in patients who relapsed than in those remaining in remission. Eye signs were not associated with relapse or presence of antibodies.

Our finding that HLA-DR3 did not predict relapse confirms the results of three other prospective studies..$^{9-11}$ The association of relapse with the presence of HLA-Cw7 and of remission with HLA-DR4 has not been reported previously; table III shows the combined influence of these phenotypes. In patients positive for HLA-Cw7 the absence or presence of DR4 did not seem to alter the increased risk of relapse; patients with an HLA-DR4 positive HLA-Cw7 negative phenotype seemed to be protected against relapse; and in those negative for both HLA-Cw7 and DR4 the numbers of patients who relapsed or were in remission were similar.

TABLE III-Distribution of HLA-Cw7 and DR4 and relation with long term relapse or remission

\begin{tabular}{lcccc}
\hline & $\begin{array}{c}\text { Cw7 positive, } \\
\text { DR4 negative } \\
(\mathrm{n}=26)\end{array}$ & $\begin{array}{c}\text { Cw7 positive, } \\
\text { DR4 positive } \\
(\mathrm{n}=4)\end{array}$ & $\begin{array}{c}\text { Cw7 negative, } \\
\text { DR4 positive } \\
(\mathrm{n}=7)\end{array}$ & $\begin{array}{c}\text { Cw7 negative, } \\
\text { DR4 negative } \\
(\mathrm{n}=21)\end{array}$ \\
\hline Patients who relapsed & 20 & 3 & 0 & 11 \\
Patients in remission & 6 & 1 & 7 & 10 \\
\hline
\end{tabular}

The significance found for HLA-DR4 and Cw7, however, was lost when, as is customary in analysis in applied immunogenetics, ${ }^{18}$ the $p$ value was multiplied by the number of antigens tested. A relation between DR4 specificity and increased synthesis of microsomal antibody in postpartum thyroiditis has been described..$^{23}$ Previous reports showed that the prevalence of HLA-DR4 was not significantly decreased in patients with Graves' disease compared with the normal population. ${ }^{24-26}$ No data are available on patients who relapsed; our results suggesting a relation between the presence of DR4 and remission and the presence of $\mathrm{Cw} 7$ and relapse therefore need to be confirmed.

The presence of HLA-DR4 was also significantly associated with the absence of antibodies to the thyroid stimulating hormone receptor, whereas HLA-Cw7 specificity was not related to the presence or absence of antibodies or to other immunological variables. Notably, the four patients with antibodies to the receptor who relapsed were all negative for HLA-DR4 as expected but also for HLA-Cw7. The abnormal immune response in Graves' disease, which results in synthesis of autoantibodies against the thyroid stimulating hormone receptor, has been linked to the abnormal expression of HLA-DR and HLA-DQ on thyroid follicular cells ${ }^{27}$ and is associated with HLA-DR3 ${ }^{6}$ The level of this antibody is known to decrease during antithyroid drug treatment. ${ }^{26-8112021}$ Recently, numbers of activated $T$ suppressor cells were shown to increase and numbers of activated $\mathrm{T}$ helper cells to decrease during drug treatment; this resulted in reduced synthesis of thyroid autoantibodies as indicated by lower serum titres. ${ }^{28}$ Our data suggest an association between the HLA-DR4 phenotype and both the absence of antibody to the thyroid stimulating hormone receptor and permanent remission after treatment. The HLA-DR4 phenotype may perhaps be associated with immunomodulation, which is probably enhanced by antithyroid drug treatment: in such people lymphocytes might have a decreased rate of synthesis of autoantibodies, which might eventually result in a higher chance of remission.

Our results support a recent hypothesis that some HLA antigens may promote the development of autoimmune disease whereas others may have a protective action. ${ }^{29}$

In conclusion, HLA-Cw7, antibodies to thyroid stimulating hormone receptor at the end of treatment, and a large goitre were found more commonly in patients who relapsed. The presence of HLA-DR4 as well as the absence of antibodies was associated with remission. HLA-DR4 may protect against relapse of thyrotoxicosis, possibly by immunomodulation resulting in inhibition of synthesis 
of pathogenic antibodies to the thyroid stimulating hormone receptor.

The Netherlands Organisation for Medical and Health Research (MEDIGON) and the Advancement of Pure Research (ZWO) provided financial support for this study. Drs J D'Amaro and P de Lange performed part of the Woolfe-Haldane analysis. We thank Rineke de Graaf and Carina van den Haak for typing the manuscript.

\section{References}

1 Adams DD. Thyroid-stimulating autoantibodies. Vitam Horm 1980;38:119-203.

2 Burman KD, Baker JR Jr. Immune mechanisms in Graves' disease. Endocr Rev 1985;6:183-232.

3 DeGroot LJ, Stanbury JB. The thyroid and its diseases. 4th ed. New York: John Wiley and Sons, 1975:249-367.

4 McKenzie JM, Zakarija M. Hyperthyroidism. In: DeGroot L, Cahill GF, Odell WO, et al, eds. Endocrinology. Vol 1. New York: Grune and Stratton, 1980:429-59.

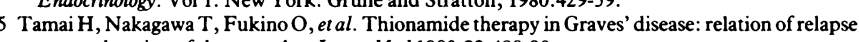
rate to duration of therapy. Ann Intern Med 1980;92:488-90.

6 Farid NR, Bear JC. The human major histocompatibility complex and endocrine disease. Endocr Rev 1981;2:50-86.

7 McGregor AM, Smith BR, Hall R, Petersen MM, Miller M, Dewar PJ. Prediction of relapse in hyperthyroid Graves' disease. Lancet 1980;i:1101-3.

8 Teng CS, Yeung RTT. Changes in thyroid-stimulating antibody activity in Graves' disease treated with antithyroid drugs and its relationship to relapse: a prospective study. $\mathcal{J}$ Clin Endocrinol Metab 1980;50:144-7.

9 Allanic H, Fauchet R, Lorcy Y, Guenquen M, Le Guerrier A-M, Genetet B. A prospective study of the relationship between relapse of hyperthyroid Graves' disease after antithyroid drugs and HLA haplotype. J Clin Endocrinol Metab 1983;57:719-22.

10 Wilson R, McKillop JH, Henderson N, Pearson DW, Thomson JA. The ability of the serum thyrotrophin receptor antibody (TRAb) index and HLA-status to predict long-term remission of thyrotoxicosis following medical therapy for Graves' disease. Clin Endocrinol (Oxf) 1986;25: $151-6$.

11 Weetman AP, Ratanachaiyavong S, Middleton GW, et al. Prediction of outcome in Graves' disease after carbimazole treatment. Qf Med 1986;59:409-19.

12 Werner SC. Modification of the classification of the eye changes of Graves' disease: recommendations of the ad hoc committee of the American Thyroid Association. 7 Clin Endocrinol Metab 1977;44:203-4.
13 Van der Heide D, Daha MR, Bolk JH, et al. Circulating immune complexes and thyroidstimulating immunoglobulins before, during, and after antithyroid drug therapy in patients with Graves' disease. Lancet 1980; 1 :1376-80.

14 Mittal KD, Mickey MR, Singal DP, Terasaki PI. Serotyping for homotransplantation. XVIII. Refinement of microdroplet lymphocyte toxicity test. Transplantation 1968;6:913-27.

15 Van Rood JJ, van Leeuwen A, Ploem JS. Simultaneous detection of two cell populations by two-colour fluorescence and application to the recognition of B-cell determinants. Nature two-colour fluor $1976 ; 262: 795-7$.

16 Woolf B. On estimating the relation between blood group and disease. Ann Hum Genet 1955;19:251-3.

17 Haldane JBS. The estimation and significance of the logarithm of a ratio of frequencies. Ann Hum Genet 1955;20:309-11.

18 Svejgaard A, Platz B, Ryder LP. HLA and disease susceptibility: clinical implications. Cinics in Immunology and Allergy. 1984;4:567-80.

19 Reinwein D, Benker G, König M-P, et al. Hyperthyroidism in Europe: clinical and laboratory data of a prospective multicentre study. F Endocrinol Invest 1986;9(suppl 2):1-35.

20 Davies TF, Yeo PPB, Evered DC, Clark F, Smith BR, Hall R. Value of thyroid-stimulating antibody determinations in predicting short-term thyrotoxic relapse in Graves' disease. Lancet 1977;ii:1181-2.

21 O’Donnell J, Trokoudes K, Silverberg J, Row VV, Volpé R. Thyrotropin displacement activity of serum immunoglobulins from patients with Graves' disease. $\mathcal{f}$ Clin Endocrinol Metab 1978;46:770-7.

22 Laurberg P, Hausen PEB, Iversen E, Jensen SE, Weeke J. Goitre size and outcome of medical reatment of Graves' disease. Acta Endocrinol (Copenh) 1986;111:39-43.

23 Jansson R, Säfwenberg J, Dahlberg PA. Influence of the HLA-DR4 antigen and iodine status on the development of autoimmune postpartum thyroiditis. F Clin Endocrinol Metab 1985;60: 168-73.

24 Bech K, Lumholtz B, Nerup J, et al. HLA antigens in Graves' disease. Acta Endocrinol (Copenh) 1977;86:510-6.

25 Dahlberg PA, Holmlund G, Karlsson EA, Safwenberg J. HLA-A;B;C; and DR antigens in patients with Graves' disease and their correlation with signs and clinical course. Acta Endocrinol (Copenh) 1981;97:42-7.

26 Allanic H, Fauchet R, Lorcy Y, et al. HLA and Graves' disease: an association with HLA-DRw3. $f$ Clin Endocrinol Metab 1980;51:863-7.

27 Hanafusa T, Pujol-Borrell R, Chiovato L, Russell RCG, Doniach D, Botazzo GF. Aberrant expression of HLA-DR antigen on thyrocytes in Graves' disease: relevance for autoimmunity. Lancet 1983;ii:1111-5.

28 Tötterman TH, Karlsson FA, Bengtsson M, Mendel-Hartvig I. Introduction of circulating activated suppressor-like T cells by methimazole therapy for Graves' disease. $N$ Engl f Med 1987;316:15-22.

29 Adams DD. Protection from autoimmune disease as the third function of the major histocompatibility gene complex. Lancet 1987;ii:245-9.

(Accepted 23 December 1987)

\title{
Prevalence, concentration, and prognostic importance of proteinuria in patients with malignancies
}

\author{
NICK SAWYER, JANE WADSWORTH, MARC WIJNEN, ROGER GABRIEL
}

\begin{abstract}
Protein was found significantly more frequently in single urine samples from 504 patients with malignancy $(290 ; 58 \%)$ than in 529 controls $(119 ; 22 \%)(p<0.001)$. Median protein concentration was greater $(p<0.001)$ in patients with neoplasia $(0.14 \mathrm{~g} / 1)$ than in controls $(0.07 \mathrm{~g} / \mathrm{l})$. Actuarial analysis showed a median survival of 4.5 months in patients with proteinuria compared with 10 months in those without $(p<0.001)$. The association between proteinuria and shorter survival was statistically significant for patients with gut tumours, lung tumours, and tumours at other sites analysed
\end{abstract}

Renal Unit, St Mary's Hospital, London W2 1NY

NICK SAWYER, MB, MRCP, research registrar

MARC WIJNEN, medical student

ROGER GABRIEL, MSC, FRCP, renal physician Department of Community Medicine, St Mary's Hospital Medical School,
London

JANE WADSWORTH, BSC, MSC, lecturer in statistics

Correspondence to: Dr Gabriel. as a group. Patients with myeloma or urinary tract tumours were not studied.

In many patients with malignancy the presence of proteinuria may be associated with a substantially reduced survival time.

\section{Introduction}

Proteinuria, often heavy, is an infrequent but well recognised complication of many different malignancies. ${ }^{12}$ Histologically membranous nephropathy is most often present, ${ }^{34}$ but minimal change is typically found in patients with lymphomas. ${ }^{56}$ Tumour products were detected in glomeruli in a patient with colonic carcinoma ${ }^{7}$ and tumour antigen was eluted from the kidneys of a patient with the nephrotic syndrome and malignant melanoma. ${ }^{8}$ Renal tissue obtained at necropsy from patients who had reticuloendothelial tumours contained C3, immunoglobulins, and electron dense deposits in glomeruli, ${ }^{910}$ suggesting subclinical deposition of immune complexes. These observations were confirmed in patients who had died of gut tumours. ${ }^{11}$

Low concentrations of proteinuria may be found in patients with advanced neoplastic disease ${ }^{12}$ and extrarenal carcinomas. ${ }^{13}$ The Framingham study showed that proteinuria was associated with increased mortality after controlling for cardiovascular risk factors. ${ }^{14}$ The data are being examined to see whether proteinuria 